\title{
Netbaseret undervisning - en tillidssag
}

\author{
Hanne Longreen \\ Lektor, Kommunikation \\ Roskilde Universitetscenter \\ hannel@ruc.dk \\ http://www.ruc.dk/komm/Ansatte/vip/HANNEL/
}

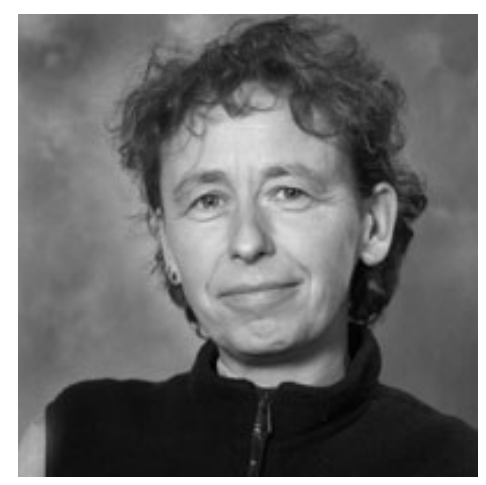

Larer på Master i Professionel Kommunikation (MPK, tidligere InterKomm).

Artiklen tager afsæt i forfatterens egne oplevelser erfaret dels fra skolebænken og dels bag katederet. Målet for artiklen er at søge at sætte ord på, hvordan den netbaserede undervisning kan fungere som et virtuelt frirum med det formål at skabe tillidsfulde reflekterede praktikere af de studerende. Artiklen fremstår som en skriftlig selvreflekterende tekst og ikke som en klassisk videnskabelig artikel med referencer til videnskabelige kilder.

\section{Indledning}

Da jeg gik i 7.klasse, fortalte vores matematiklærer os en historie om, hvordan en lærer kunne få det bedste frem i sine elever. Fascineret hørte jeg ham fortælle om et forsøg, hvor man havde målt, hvad der skete med elevers indlæring, når de enten var i et positivt eller i et negativt læringsmiljø. I det positive læringsmiljø opmuntrede læreren hele tiden eleverne ved at fremhæve det, de var gode til, mens læreren i det negative læringsmiljø hele tiden trak fejl og mangler frem og kun fremhævede det, der ikke var godt. I det læringsrum, hvor eleverne fik følelsen af, at de var humlebier og kunne flyve, gik det rigtig godt, mens der i det miljø, hvor de konstant fik at vide, at det var de i hvert fald ikke, var det faglige niveau lavere.

Siden 7. klasse har denne historie fulgt mig på flere måder. På egen krop har jeg følt, hvad det betød at blive mødt med en åben og positiv holdning, og hvordan den negative lærer simpelthen kunne få mig til at stamme, fumle og gå i sort. I folkeskolen fik jeg at vide, at jeg ikke kunne stave og blev konstant fremhævet som umulig, når diktaten blev gennemgået $\mathrm{i}$ klassen. På gymnasiet havde jeg sjældent stavefejl. Her forsøgte læreren at sætte fokus på det skriftlige som produkt og dermed på, hvordan sprogrigtigheden var vigtig for, at man blev forstået. Produktet kunne altid blive bedre - i folkeskolen var der ikke noget at gøre, jeg var, som person, simpelthen problemet.

Da jeg kom om på den anden side af katederet, var det pludselig mig, der magtfuldt kunne bestemme, hvordan jeg ville undervise - om jeg skulle udvikle mig til en lektor Blomme eller en Dr. Goodwill? På universitetsniveau var det svært at finde gode pædagogiske lærerollemodeller. Undervisningspædagogikken har aldrig rigtig været noget hit på de højere læreranstal- 
ter. Ansvaret for læring var - de fleste steder - alene den studerendes. Hvis man ikke forstod, hvad der blev sagt, var det nok, fordi man var "dum”. Dette billede er ved at ændre sig. I de senere år er et pædagogisk kursus blevet obligatorisk, før man kan fastansættes. At den unge jurastuderende ikke forstår, hvad der bliver undervist i, er nu også et ansvar for underviseren. Dette ansvar for læringen, og hvordan man takler dette som lærer, er altså noget der er relativt nyt på universitetsniveau.

\section{Læringsrum}

Når jeg har gjort så forholdsvist meget ud af at beskrive disse to modsætningsfulde læringsrum og forholdt det til, hvordan pædagogik vægtes på universitetet, er det fordi, det efter min mening er ret betydende grundvilkår for det læringsrum, der skal skabes på en netbaseret uddannelse på universitetsniveau. Og det er jo på det niveau, de netbaserede masteruddannelser (MCC, Master i IKT og Læring, MPK m.fl) befinder sig. Hvordan kommer man som lærer rundt om at skabe læringsrum, der kan skabe rammerne for en udviklende og fagligt inspirerende læringsproces på et højt akademisk niveau, når man samtidig skal overkomme det særlige forhold, at undervisningen mestendels foregår på nettet? Jeg vil næsten sige, det var lettere, da pædagogikken formulerede lærerrollen som tankpasser: Hvis blot den studerende hørte ordentlig efter, fulgte med i timerne og læste på lektien, så var det lærerens rolle blot at fylde viden på den studerende. Viden er noget, der i denne pædagogiske tænkning, overføres fra læreren til den studerende. Den studerende skal bare slå ørerne ud og lytte - det er vel egentlig også derfor, den studerende har ører? Har man imidlertid et humlebis-ideal, så er der stort set ikke andet end udfordringer, for humlebis-idealet er jo ikke blot den altid positive lærer, men også en lærer, der vil skabe rum for kvalitativ faglig læring. Udfordringen er altså for det første at forholde sig til at udvikle en didaktik, for det andet at omsætte denne didaktik i et virtuelt læringsrum.

Og som om dette ikke er nok, så er der endnu et parameter, som ikke er til at komme udenom. Dette tredje parameter relaterer sig til, hvorvidt netuddannelsens har et særligt pædagogiske brand. I forhold til de uddannelser jeg underviser på (Interkomm, http://www.interkomm.ruc.dk/ og MPK, http://www.mpk.ruc.dk/), så er det tværfaglige projektgruppearbejde dette brand. Noget af en mundfuld. Som lærer skal jeg altså, udfra mine egne idealer, stille op med en rumlig didaktik, der endvidere skal overføres til et virtuelt klasselokale, og dertil få de studerende til at studere (og ikke blot arbejde) i grupper. Jeg skal altså ikke blot sørge for, at der er et åbent og trygt miljø, hvor intet spørgsmål er for dumt, hvor alle kan være med, men samtidig holde det faglige niveau på et universitetsniveau.

Læring er ikke længere blot et spørgsmål om min faglige viden, men også om mine kompetencer til at skabe rammerne for læringen. Et nøglebegreb i denne sammenhæng er tillid. Der, hvor jeg møder de studerende face-to-face og i de skriftlige netbaserede undervisningsforløb, skal der opbygges tillid. I face-to-face undervisningen kan jeg med mimik, gestik og nonverbal kommunikation skabe tryghed og tillid i læreprocessen. Dette er straks vanskelige på nettet, hvor ord og vendinger kommer til at stå meget alene. Der læses ikke blot én gang, men vendes og drejes for at vride alle de betydninger ud, som måtte ligge bag. Her i dette kropsløse, virtuelle læringsrum er man meget sårbar som studerende. En forudsætning for læringen er, at der hersker tillidsforhold mellem læreren og den enkelte studerende, men så sandelig også de studerende imellem. Derfor skal man som lærer være meget opmærksom på, hvordan man kommunikerer. Fremsat kritik skal altid følges af konkrete forslag til, hvordan man kan gøre det bedre. 


\section{En lærer er en lærer er en Iærer}

Ud over det specifikke omkring tillid, er det min erfaring, at det vanskelige ikke ligger på det tekniske niveau, at vi skal kommunikere via nettet, nej, det vanskelige er at få udfordret de forventninger og erfaringer, som de studerende har, når de møder op på den netbaserede uddannelse. De studerende, jeg gennem årene har haft med at gøre, er alle modne mennesker, der har mindst tre års relevant erhvervserfaring. De ved godt, hvad undervisning er, hvad en lærer skal gøre, hvad gruppearbejde er, ja, de har som regel meget fasttømrede forestillinger og forventninger til, hvilken rolle jeg som lærer har og skal have. Disse forestillinger skal selvsagt udfordres ved, at man som lærer gør klart, hvori man ser sin egen rolle som lærer i relation til de studerendes læringsproces.

Læringen handler altså ikke blot om det læringsrum, man som lærer skal etablere, nej, det handler også om at se på ens egen rolle som lærer og forholde den til det særlige, at man er lærer på en netbaseret uddannelse. Men som lærer på en netbaseret uddannelse har man flere funktioner, idet man ikke alene skal forholde sig til det faglige, men også til den måde de studerende kommunikerer indbyrdes med hinanden på nettet. Som lærer skal man sætte den etiske standard for, hvordan man kommunikerer, således at der skabes størst mulig tillid i det virtuelle læringsrum.

Som lærer er man således ikke kun en faglig person, men også forpligtet på at opretholde et konstruktivt læringsmiljø i det virtuelle læringsrum - og dette er nok en af de store forskelle set i forhold til face-to-face undervisningen. Som lærer i det virtuelle læringsrum er du "på" hele tiden og ikke blot i de konkrete timer, hvor der er sat tid for din undervisning. At du i princippet er "på" hele tiden medfører, at man som lærer må sørge for at have faste tider, hvor de studerende kan træffe en dvs. være sikre på, at de kan få fat i dig. Faste træffetider, dvs. et fastsat tidspunkt, hvor de studerende ved at der ligger et svar fra dig, er derfor en nødvendighed.

Ovenstående handler om de rammer, man kan sætte som en god "vært”. Men hvordan gør man det så i praksis? Først og fremmest er det min erfaring, at man gennem det skriftlige sprog skal tydeliggøre, at det, man som lærer ønsker af de studerende, er erkendelsestekster og ikke formidlingstekster. Forskellen på de to forskellige typer tekster er, at førstnævnte er "tænke-tekster": man skriver det, man overvejer, hvor den sidste type tekst er den tekst, man afleverer til allersidst f.eks. det færdige oplæg eller den færdige projektrapport. Tænketeksterne er ufærdige tekster, er kladder. At vi således omgår hinanden skriftligt i kladdeform, at jeg går ind og kommenterer og stiller spørgsmål inde i de studerendes tekster, er med til at tydeliggøre, at vi er i proces, at de tekster, vi arbejder med, er under udvikling. Det tager trykket af de studerendes præstationspres og skaber rammerne for en konstruktiv læringsproces.

\section{Hvordan bliver de studerende til faglige humlebier?}

Når tilliden er oprettet og er sikret gennem faste rammer, hvad er så min opskrift på humlebislæreren i det virtuelle læringsrum?

For det første er det altafgørende at få de studerende til at aflægge de forestillinger og forventninger, de møder op med. De skal forstyrres. Det kan man konkret gøre ved at lade de studerende læse forskellige tekster, der har det samme emne, men som når frem til forskellige konklusioner. Man kan f.eks. vælge forskellige skoler eller teoretiske retninger, der behandler det samme emne. På den måde ser de studerende, at der er mere end én sandhed - og det er rystende, for kan der være tale om, at en sandhed er mere sand end en anden? Det er i sandhed forstyrrende. 
Næste trin er at gøre forstyrelsen produktiv. Her er det, man som lærer skal lære de studerende at stille spørgsmål til teksten. Læringen foregår ikke ved at teksten skal læres for tekstens skyld, men teksten skal derimod give svar på spørgsmål, som er relevante i forbindelse med studiet.

Dette andet trin forudsætter, at læringen sker fokuseret, dvs. at den studerende formulerer et problemfelt, som gør læsningen relevant. Der er ikke tale om udenadslære, men om læring der foregår refleksivt. Den fokuserede læringsproces kan også etableres gennem case-arbejde. Har jeg f.eks. en teoretisk tekst, der handler om kulturbegreber, så finder jeg f.eks. en hjemmeside, hvor jeg beder de studerende om at analysere teksten udfra de kulturbegreber den udleverede teoretiske tekst behandler. Det kan f.eks. være hjemmesiden for den selvstændige canadiske region Nunavut, som skal analyseres udfra Kirstens Hastrups (1989) artikel "Kultur som analytisk begreb". Til støtte for den studerendes arbejde stiller jeg så nogle spørgsmål, som typisk handler om, at de studerende skal komme med to - tre overvejelser over, hvordan kultur konkret kan forstås i forhold til hjemmesiden. Min strategi som lærer er altså ikke at give entydige svar, men at stille spørgsmål, der kræver at de studerende formulerer flere spørgsmål, hvorved de på den måde får åbnet det faglige område op, så det kan belyses og behandles refleksivt. Læringen handler altså om, at det faglige kontinuerligt udfordres i den enkelte studerende, mellem de enkelte studerende i projektgruppen, mellem alle deltagere i undervisningen og mellem læreren og de studerende. Den faglige viden genereres gennem denne proces.

Refleksive praktikere er endemålet for den læringsproces, jeg gerne vil sætte i gang. Læringen har det formål, at den studerende kan reflektere og dermed kvalificere de resultater, som fremkommer gennem læringsprocessen, samt kunne omsætte disse i faktiske handlinger. Dette oplever jeg som et vigtigt endemål med de netbaserede masteruddannelser, at de bidrager til at gøre den enkelte i stand til at få overblik og træffe de bedste valg i konkrete situationer.

Jeg synes faktisk, det er blevet meget sjovere at være lærer, siden jeg opdagede, at jeg ikke skal være Den Store Bastian, men være Spørge-Jørgens klon.

\section{Litteratur}

Hastrup, Kirsten.”Kultur som analytisk begreb”. Hastrup, Kirsten og Kirsten Ramløv (eds): Kulturanalyse, Akademisk Forlag, København 1989. 